IZA DP No. 4582

Investment in Human Capital during Incarceration and Employment Prospects of Prisoners

Margaret Giles

Anh T. Le

November 2009 


\title{
Investment in Human Capital during Incarceration and Employment Prospects of Prisoners
}

\author{
Margaret Giles \\ Edith Cowan University \\ Anh T. Le \\ University of Western Australia \\ and IZA \\ Discussion Paper No. 4582 \\ November 2009 \\ IZA \\ P.O. Box 7240 \\ 53072 Bonn \\ Germany \\ Phone: +49-228-3894-0 \\ Fax: +49-228-3894-180 \\ E-mail: iza@iza.org
}

Any opinions expressed here are those of the author(s) and not those of IZA. Research published in this series may include views on policy, but the institute itself takes no institutional policy positions.

The Institute for the Study of Labor (IZA) in Bonn is a local and virtual international research center and a place of communication between science, politics and business. IZA is an independent nonprofit organization supported by Deutsche Post Foundation. The center is associated with the University of Bonn and offers a stimulating research environment through its international network, workshops and conferences, data service, project support, research visits and doctoral program. IZA engages in (i) original and internationally competitive research in all fields of labor economics, (ii) development of policy concepts, and (iii) dissemination of research results and concepts to the interested public.

IZA Discussion Papers often represent preliminary work and are circulated to encourage discussion. Citation of such a paper should account for its provisional character. A revised version may be available directly from the author. 
IZA Discussion Paper No. 4582

November 2009

\section{ABSTRACT \\ Investment in Human Capital during Incarceration and Employment Prospects of Prisoners}

The costs of incarceration and recidivism to the community are substantial. These costs not only include the direct costs of imprisonment but also the opportunity costs arising from depletion of human capital and loss of output. Policy makers have emphasised the importance of rehabilitating prisoners as a way of reducing recidivism. Consequently, the management of prisoners has changed, with more prisoners being encouraged to undertake some form of education, training and/or work during their incarceration in conjunction with any behavioural management programmes. This paper examines, using the 2003 Survey of Prisoners in Western Australia, the decision of prisoners to invest in education/training during their prison term and the potential labour market outcomes of this investment. The results suggest that prisoners use education/training to improve their skills in preparation for release from prison. From this perspective it can be argued that these prisoners see education/training as an investment in human capital rather than consumption. In addition, the decision to participate in either education or training is non-random and varies across the time remaining on the prison sentence, thus suggesting prisoners view education and training as different activities. However, the results show the expected benefit prisoners place on education and training is similar.

JEL Classification: $\quad$ I20, J01, J21

Keywords: prisoners, education, training, employment

Corresponding author:

Anh T. Le

Business School

Mail Bag M251 (Economics)

The University of Western Australia

35 Stirling Highway

Crawley, WA 6009

Australia

E-mail: Anh.Tram.Le@uwa.edu.au 


\section{INVESTMENT IN HUMAN CAPITAL DURING INCARCERATION AND EMPLOYMENT PROSPECTS OF PRISONERS}

\section{INTRODUCTION}

Most literature suggests that crime incidence and recidivism are inversely related to the educational attainment and employment of the individual (e.g., Kling and Krueger 2001; Batchelder and Pippert 2002; Social Exclusion Unit Great Britian 2002; Chavez and Dawe 2007). For example, Lochner and Moretti (2004) argue that the impact of education is twofold. First, education increases the opportunity cost of crime and the cost of time spent in prison. Second, they suggest that education makes individuals less impatient (referring to the role of impetuosity of youth in escalating crime rates among teenagers) and more risk averse. Both effects reduce the propensity of committing crimes, even when controlling as they do for individual ability and family background. Riddell (2006, p.21) also suggests that "education may also raise an individual's rate of time preference (the extent to which future consequences are discounted), thus increasing the cost of any future punishment that is the result of crime”.

At the aggregate level, crime incidence and recidivism increase when growth slows and unemployment rates rise (see The United Nations Asia and Far East Institute for the Prevention of Crime and the Treatment of Offenders (UNAFEI) 2008, in relation to the increasing prison population in Japan due to recession in the economy since 1995).

For the individual, having a criminal record, including imprisonment, can contribute to poor labour market outcomes. From an economic perspective, the lack of labour market success implies that ex-prisoners will be more reliant on social welfare such as benefit payments, health, housing and community care and labour market programs, all of which increase the financial burden on society. For example, the estimated direct cost of assistance to the unemployed for 2007-08 was \$A9,312 per unemployed person (Commonwealth of Australia 2008). ${ }^{1}$ The annual cost of incarceration in 2007-2008 was \$A99,612 per prisoner (Western Australia Department of Justice 2008). Hence, a reduction in the number of offenders, reoffenders and incarcerations can lead to substantial cost savings for the government.

\footnotetext{
${ }^{1}$ The total estimated assistance to the unemployed was $\$ \mathrm{~A} 4,288$ million. The estimated number of unemployed was 460.5 thousand.
} 
In Australia since the 1970s, the education/training and work experience of prisoners during their period of incarceration have been increasingly scrutinised. For example, in 1996 the Senate Employment, Education and Training References Committee (SEETRC) reported on its nation-wide appraisal of the education and training of people in adult and juvenile correctional facilities in the context of the National Training Reform Agenda. The Committee was to "establish guidelines and principals for the participation of adults and juveniles in custody in education and accredited vocational training, and for their access to the range of lifelong learning opportunities available to the community at large” (SEETRC 1996, p.ii).

Following the SEETRC recommendations, a framework for a national strategy for vocational education and training for adult prisoners and offenders was adopted (Australian National Training Authority (ANTA) 2001). The aim was to "provide adult prisoners and offenders with education and vocational pathways which will support their productive contribution to the economic and social life of the community” (ANTA 2001, p.3). These pathways included ensuring continuity of studies for prisoners moving between prisons, providing learning support, ensuring that training is linked to realistic employment opportunities and ensuring that education and training are provided within the national training framework. In addition, there was to be better cooperation between prisons, Vocational Education and Training (VET) providers and other stakeholders at both custody and immediate post-release stages (see Dawe 2007 for a summary of this background).

There are a number of considerations with regard to the provision of education/training in prison. For instance, it is not just a matter of allowing education/training and work to be available on site. Recognition needs to be given to other factors in the prisoners' background, such as their offences, substance abuse history, mental and physical health and plans for the future. In addition, there are challenges for prison authorities, such as maintaining security. While policy makers see the benefits of re-education or training prisoners, it is not clear that the prisoners themselves value opportunities for investment in human capital. For example, there are suggestions that attendance at education courses inside prison is just to 'pass the time’ (Cook 1990).

This paper has two objectives. First, we will focus on human capital investment among prisoners. We will begin by examining the prisoners' educational attainment prior to their current incarceration. This serves to provide useful 
background on the factors that affect the prisoners' educational attainment as well as informing whether the results obtained from the current data set are comparable to those from the literature. Following from this, we will examine the prisoners' human capital investment during incarceration. Human capital investment includes educational courses as well as training courses. ${ }^{2}$ We will explore the prisoners' participation in education/training at the time of the survey (termed 'current' participation) through various stages of their prison sentence. We will be able to determine if the decision to invest in education or training differs by time remaining on the prison term. In addition, by examining the prisoners' current participation in education/training in conjunction with the time of their release we will be able to make some inferences whether prisoners undertake education/training as an investment or to 'pass the time' (for consumption). This distinction is important as it can affect the prisoners' choice of courses and completion of courses as well as their labour market aspirations. Furthermore, knowing the prisoners' intention to invest in human capital during incarceration can be useful to policy makers in the rehabilitation of prisoners and allocation of prisoners to certain courses.

Second, in order to make inferences on the value prisoners place on the education/training received during incarceration, two potential outcomes of the prisoners' investment in human capital will be explored, namely the possibilities of finding a job or a better job after imprisonment. These two outcomes are treated as mutually exclusive and will be examined separately for those prisoners undertaking education and those undertaking training. In light of the changes that have been made by policy makers to rehabilitate prisoners, it is important to determine the value prisoners place on their rehabilitation via investment in human capital as well as the potential outcomes of their investment.

The results show that there are a number of factors that can explain the difference in human capital investment between prisoners who completed Year 12 or higher prior to their current incarceration and those who completed Year 11 or lower prior to their current incarceration. There is a non trivial difference between the decision to participate in education and the decision to participate in training. Hence, the two activities are quite separate. The results suggest prisoners who are clear about

\footnotetext{
${ }^{2}$ Education includes school-type subjects, literacy and numeracy programmes and higher education courses. Training includes Federally-funded Technical and Further Education (TAFE) subjects and vocational training courses.
} 
their labour market participation after imprisonment use education/training to improve their skills. The values prisoners place on their participation in education or training courses appears to be similar, however.

The remainder of the paper is organised as follows. Section 2 briefly discusses correctional education, training and work in Western Australian prisons as well as the literature. Section 3 provides a discussion of the data and methodology. Section 4 discusses the results. A conclusion is presented in Section 5. 


\section{BACKGROUND}

The developments in prison education in Western Australia (WA) mirror education developments in other jurisdictions. By the 1970s the government was attempting to formalise the availability of education in prisons. Most prisons have combinations of work, study and behaviour management programs available to remand and sentenced prisoners. These are intended to provide inmates with life- and employment-related skills as well as daily structure. There are also community benefits, for example sociologists argue that education is also empowerment (Reuss 1999).

Since 1902 when the first professional educator to teach adults in prisons was appointed, correctional education in WA metropolitan and regional prisons has had diverse offerings - adult basic education, post-compulsory schooling, VET and higher education. The focus of these courses was remedial, that is, to reduce the perceived educational deficiency of prisoners relative to the general population. In recent times, while the attainment of literacy and numeracy competencies is offered to many prisoners, the acquisition of skills to gain and maintain employment in the community has become increasingly important.

In the late 1990s, the (then) WA Department of Justice (WA DOJ) became a registered training organisation trading under the name Auswest Specialist Education and Training Services. In 2003 WA prisons for adult offenders offered nationally accredited training. This means that accredited courses inside prison had recognition outside prison. The courses delivered include Federally-funded Technical and Further Education (TAFE) courses, and courses delivered by WA DOJ staff and other registered training organisations or private providers under subcontract to WA DOJ. Note that non-TAFE delivered courses were often TAFE recognised. Courses included short half-day sessions resulting in certificates for attendance as well as structured VET and higher education study programs requiring passing minimum competencies.

In WA, all newly sentenced prisoners undergo a comprehensive assessment to determine their security rating, health requirements, work placements and programs, and educational needs (Department of Corrective Services 2009). This assessment results in each prisoner having an individual management plan. This plan also covers sentencing and parole requirements. It should be noted that education, training and work are not mandatory in WA prisons. Once admitted into prison, prison staff 
discuss with the prisoner the current availability of jobs and courses. Prison work includes maintenance of prison living or domestic work (such as cleaning living quarters and preparing meals) as well as structured work in prison industries or commercial work (including catering and factory production). Decisions about work and education/training made during these discussions are then included in the individual management plan. The plans are renewed every three to six months or after transfer to a new prison or security level. The original plan does not preclude later participation in education/training or work.

Activity rates differ across prisons due to features of specific prisons. For example, minimum-security prisons tend to have lots of activities, both work and study. These are seen as exit prisons which tend to have better behaved prisoners as well as those who are starting to reconnect with the community. In maximum-security prisons, prisoners are escorted between different parts of the prison (for example, to the library or training rooms). Some prisoners in punishment are removed from the general prison population and their access to work and study is suspended.

Prisoners who worked in commercial or domestic work in prisons in 2003 were paid weekly gratuities ranging from $\$ 16$ to $\$ 49$. This provided a strong incentive for prisoners to engage in work relative to study for which no gratuity was paid. Interestingly, many prisoners worked to obtain the gratuity but also studied. The gratuity system was overhauled in 2004 with a revised weekly rate of up to \$50 and the distribution of available gratuities now applies to both study and work. This can be seen as a way of encouraging prisoners to participate in some education/training during their incarceration. ${ }^{3}$

A number of Australian and overseas studies have provided descriptive analyses of prior education, training and work experiences of prisoners. The main finding from these studies is that a large proportion of the prison population has minimal schooling and limited prior work experience. For example, a Western Australian study in 2005 of 137 female prisoners (Western Australian Department of Corrective Services 2006) reported that $72 \%$ of inmates had only completed year 10 , although there is a great disparity in rates between Indigenous (83\%) and nonIndigenous (66\%) prisoners. In the U.K. a 1998 study of 567 female adult and

\footnotetext{
${ }^{3}$ Given that the new distribution of gratuities was implemented after the current survey was undertaken, it will be interesting in future research to compare the education/training choice of prisoners across the two sample periods.
} 
juvenile prisoners found that $74 \%$ had left high school at 15 or $16,37 \%$ had some form of further education, and 3\% were studying at the time of sentencing (Hamlyn and Lewis 2000). A 1992 study in the U.S. of 1147 inmates in 80 Federal and State prisons found that $40 \%$ had no high school diploma or General Educational Development (GED) certificate, 35\% had completed nine to 12 years of schooling, $17 \%$ had the GED certificate and 20\% had some post-secondary education (Haigler et al. 1994). A New Zealand study of 5780 prisoners in 2001 found that three-quarters of male and female prisoners had left school without educational qualifications (New Zealand Department of Corrections 2003).

In some jurisdictions, the decision of prisoners to undertake work, education and/or training during incarceration may reflect mandatory prison policies rather than an individual's desire to invest in human capital. One attempt to examine the prisoners' attitude to education was undertaken by Bearing Point (2003). This was a review of the Victorian prisons in 2002, which included a review of education and training needs of prisoners. The study found that prisoners' attitudes to education were the key factor in their willingness to participate in education and training. Other factors included age and length of prison sentence.

In the U.S. a major study of recidivism was undertaken in 1997-98. Its purpose was to examine the impact of prison education on the recidivism and employment behaviour of ex-offenders. In particular, it examined if there is any value in educating those who are incarcerated (Steurer et al. 2001). The results found that re-arrest, reconviction and re-incarceration rates were lower for those who undertook education and training while incarcerated compared with non-participants. Batchelder and Pippert (2002), in their study of choices between work and education in the U.S., found that those who thought type of work was more important than pay received for that work had longer-term goals for life outside prison. In addition, compared with violent offenders, non-violent offenders preferred study to work.

Studies which have examined the employability of prisoners have identified a number of important factors. A possible explanation for the existence of a correlation between criminality and unemployment is that crime and unemployment are fuelled by factors commonly identified in both literatures. For example, lack of stability in people's private lives can affect employment stability and re-entry into the labour market. Many ex-prisoners find that support from family and friends is withdrawn during their period of incarceration and that they commence parole with no fixed 
abode and fractured or depleted social capital (through loss of networks). These influences impact on employment opportunities as a large proportion of jobs are found through social networks. For example, around one in five jobs in 1996 were obtained through information from friends and relatives (Australian Bureau of Statistics 2001). Prisoner networks and correctional authority job preparation and placement services (such as the 'Through Care Programme (Western Australia Department of Corrective Services 2009)) help, to some extent, to replace these missing social networks, but it is not clear how successful these alternatives might be in Australia.

Periods of incarceration and homelessness send signals to employers on important 'soft skills', such as trustworthiness and reliability, and this can diminish employment prospects for ex-prisoners. In their 2001 survey of employers' preferences regarding job applicants with criminal histories, Holzer et al. (2002) found that employer's willingness to hire ex-prisoners is quite limited. This is exacerbated by low labour market demand in areas with similar demographics to the ex-prisoner population. In the absence of background checks, employers tend to resort to excluding applicants with profiles similar to ex-prisoner groups. In the U.S., young black males are particularly prone to this form of discrimination. ${ }^{4}$

Homelessness is a particular issue for job applicants, whether or not they are ex-prisoners. Not only might it signal lack of 'soft skills' but homelessness also makes it difficult for prospective employers to contact applicants for further processing and/or notification. Little Hoover Commission (1998, cited in Petersilia 2000, p.5) found that, on average, $10 \%$ of parolees in the State of California were homeless. In the major Californian cities of San Francisco and Los Angeles this figure was as high as $30 \%$ to $50 \%$.

Moreover, returning to the labour market with a gap in their employment record also signals a decay of human capital (for a review of barriers to employment, see Singley 2004). This is compounded by ex-prisoners being less skilled and less attuned to the social cues that might arise within interviews (Boshier and Johnson 1974).

Prisoners and ex-prisoners are particularly prone to poor health, both physical and mental (Dutrex 2000 and Hirsch et al. 2002 cited in Graffam et al. 2004), and low

\footnotetext{
${ }^{4}$ Whilst African American men represent 14\% of the population of young men (18-29 years) in the U.S., they represent over $40 \%$ of the prison population (Harrison and Beck 2005).
} 
self-esteem and/or motivation (Fletcher 2001 cited in Graffam et al. 2004 and Helfgott 1997). These personal characteristics are positively correlated with low participation rates, employment levels and wages. For example, many prisoners suffer depression and are on medication. This illness can commence when they are first sentenced and realise the immediate impacts of incarceration on their lives. It can also emerge during long sentences as marriages fail, children and other family members stop visiting, and family crises, such as illness or death, occur. As a result of deinstitutionalisation (this applies to Australia as well as many overseas countries), the rate of incarceration of the mentally ill has risen substantially (Fakhourya and Priebea 2007).

In addition to labour market repercussions, group dynamics (including the existence of gangs (Moore 1996 and Petersilia 2000)) and knowledge transfers in prisons can flow over into the outside world promoting anti-social behaviours such as incivility and disorder (Moore 1996), transience and loitering (Petersilia 2000) and recidivism. Petersilia (2000) states that, in the U.S., most re-arrests occur within six months of release with two thirds of all parolees being rearrested within three years. Thus, magnification of unfavourable labour market effects occurs.

While current research on prisoners provides valuable information about the characteristics of prisoners, few studies have focused on investment in human capital during incarceration. In addition, there are few quantitative studies on the value prisoners place on this investment. This paper helps fill the void by attempting to model the decision to invest in human capital during incarceration and the prisoners' expectations from this investment.

\section{DATA AND METHODOLOGY}

Data

The dataset used in this study is from the 2003 survey of five adult prisons in metropolitan areas in WA (Giles et al. 2004). The survey was conducted at two female prisons and three male prisons. The first female minimum-security prison is located in the inner metropolitan area and had a capacity of 32-45 inmates. ${ }^{5}$ The response rate of sentenced prisoners was 50\%. A second female prison which houses maximum-, medium-, and minimum-security prisoners is located in the outer

\footnotetext{
${ }^{5}$ The capacities listed here are those that applied at the time of the 2005 Survey.
} 
metropolitan area and had a capacity of 85-164 inmates. The survey response rate of sentenced prisoners here was also 50\%. One male maximum-security prison located in the outer metropolitan area had a capacity of 401-493 prisoners. The response rate was $13 \%$ of sentenced prisoners. One male minimum-security prison located in the outer metropolitan area had a capacity of 160-172 prisoners. The response rate was $87 \%$ of sentenced prisoners. A second male minimum-security prison is located in the outer metropolitan area and had a capacity of 210-232 prisoners. The response rate was $90 \%$ of sentenced prisoners. Differences in response rates were due, in part, to the ease of access interviewers had to the prisoners on the days of interview.

The data were collected by personal interviews with the prisoners. The interview process was slightly different in each of the prisons. At the maximumsecurity male prison, for example, the project team leader met with the prison support officer and prisoner support team members (both staff and prisoners) to discuss the project. The team members distributed the letters of invitation to other prisoners and made a list of prisoners who wished to participate in the survey. The list was passed to the prison officer in charge of the interview room. Unlike other prisons, the interview rooms were subjected to continual surveillance and the interview corridor was locked at both ends. Prisoners participating in the interviews in this part of the prison were required to be searched and to change clothes before entering and after leaving the interview rooms. This was a deterrent to participation and was an important reason for the low response rate at that prison. At the smallest minimum-security prison for women the prison duty officer paged each prisoner one at a time from the muster list to come to the office. Here the interviewer invited the prisoner to do the survey. If the prisoner concurred then the interview was conducted in the library. As a minimum security prison, it was easier for interviewers and prisoners to move from one part of the main building to another without prison staff escort or surveillance.

The survey data include socio-demographic information (e.g., age, gender, postcode of last residence), employment history (e.g., type of job, hours worked, earnings), past education and training (e.g., highest level of schooling, qualifications), prison information (e.g., current sentence length, types of offence) and prison education, training and work. The dataset contains information from completed surveys by 453 prisoners.

There are some differences between interviewed prisoner profiles at the five prisons. Whilst educational profiles of interviewed prisoners differed across the 
different prisons, this was not statistically significant at the $1 \%$ level. The offence profile of interviewed prisoners differed by prisons as the prisons have different security levels and offences attracting different sentencing penalties in terms of security rating and length of imprisonment. The difference in these profiles is, as expected, statistically significant at the $1 \%$ level. Another difference between prisons is the proportion of Aboriginal and Torres Strait Islander (ATSI) prisoners. This is statistically significant at the 1\% level. Prisoners' involvement in work and education/training differs between the prisons and this is statistically significant at the $5 \%$ level. The prisoner profiles are discussed below.

Table 1: Selected characteristics of prisoners

\begin{tabular}{|l|c|c|c|c|}
\hline Characteristic & Females & Males & Total & Total (\%) \\
\hline Age & & & & \\
18-25 years & 28 & 77 & 105 & 23.2 \\
$26-40$ years & 51 & 185 & 236 & 52.1 \\
41 + years & 16 & 96 & 112 & 24.7 \\
Total & 95 & 358 & 453 & 100.0 \\
\hline Partner status & 41 & 183 & 224 & 49.5 \\
$\quad$ Partnered & 53 & 175 & 228 & 50.3 \\
Not partnered & 1 & 0 & 1 & 0.2 \\
Unsure/don't know & 95 & 358 & 453 & 100.0 \\
Total & & & & \\
\hline Children & 65 & 233 & 298 & 65.8 \\
Children & 30 & 125 & 155 & 34.2 \\
No children & 95 & 358 & 453 & 100.0 \\
Total & & & & \\
\hline Educational attainment & & & & \\
Post-grad, grad dip, grad certificate, & 6 & 13 & 19 & 4.2 \\
bachelor degree & & & & \\
Advanced diploma, diploma certificate & 24 & 97 & 121 & 26.7 \\
$\quad$ Year 11, Year 12 & 64 & 247 & 311 & 68.7 \\
Year 10 and below & 1 & 1 & 2 & 0.4 \\
Other & 95 & 358 & 453 & 100.0 \\
Total & & & & \\
\hline Country of birth & 82 & 273 & 355 & 78.4 \\
Australia & 13 & 85 & 98 & 21.6 \\
Elsewhere & 95 & 358 & 453 & 100.0 \\
Total & & & & \\
\hline ATSI & 30 & 65 & 95 & 21.0 \\
ATSI & 0 & 292 & 357 & 78.8 \\
Not ATSI & 95 & 358 & 4 & 0.2 \\
Unsure/don't know & & & & \\
Total & & & \\
\hline
\end{tabular}

Table 1 presents data on selected characteristics of prisoners. It should be noted that the sample of prisoners from this survey differs from the profile of all adult 
prisoners in WA in a number of ways. For example, there is a higher representation of females in the sample compared to the total adult prison population in WA (92\% males, $8 \%$ females). The mean age of the prisoner sample is 34.4 years compared to the mean age of 36.5 years of all adult prisoners in WA. There is also an under representation of ATSI prisoners in the survey sample (21\% are ATSI) compared with $35 \%$ of adult prison population in WA at the time of the survey.

Table 2: Sentence characteristics

\begin{tabular}{|l|c|c|c|c|}
\hline Category & Females & Males & Total & Total \% \\
\hline Length of sentence & & & & \\
$1-12$ months & 27 & 59 & 86 & 19.0 \\
13 months - 60 months & 40 & 150 & 190 & 41.9 \\
61 months - 180 months & 16 & 119 & 135 & 29.8 \\
181 months - 360 months & 7 & 14 & 21 & 4.6 \\
Life sentence & 1 & 6 & 7 & 1.5 \\
Unknown length of sentence & 4 & 10 & 14 & 3.1 \\
Total & 95 & 358 & 453 & 100.0 \\
\hline Been in prison before current sentence & & & & \\
Yes & 42 & 196 & 238 & 52.5 \\
1 time & 12 & 52 & 64 & 14.1 \\
$2-5$ times & 22 & 117 & 139 & 30.7 \\
6-10 times & 4 & 16 & 20 & 4.4 \\
$11-15$ times & 0 & 7 & 7 & 1.5 \\
Unsure/don't remember/don't know & 4 & 4 & 8 & 1.8 \\
No & 53 & 162 & 215 & 47.5 \\
Total & 95 & 358 & 453 & 100.0 \\
\hline Most serious offence for current sentence & & & & \\
Offences involving drugs & 12 & 66 & 78 & 17.2 \\
Offences involving money/property & 23 & 69 & 92 & 20.3 \\
Offences involving money/property & & & & \\
\& against people & 13 & 57 & 70 & 15.5 \\
Offences against people & 30 & 106 & 136 & 30.0 \\
Other offences & 16 & 58 & 74 & 16.3 \\
Unsure/don't remember/don't know & 1 & 2 & 3 & 0.7 \\
Total & 95 & 358 & 453 & 100.0 \\
\hline
\end{tabular}

Table 2 provides data on the sentence characteristics of interviewed prisoners. About 19\% of interviewed prisoners have a sentence length of one year of less. A comparative figure is unavailable. However, the Australian Bureau of Statistics (2008) reports that 9\% of sentenced prisoners in WA in 2003 have sentence length less than one year and $51 \%$ have sentence length of less than five years. Sentence length may be important not only to the work, training and education choices prisoners may make during their incarceration but also to their employability after release (see, for example, Kling 2006). In WA access to post release employment 
programmes such as the Through Care Programme (WA Department of Corrective Services 2009), which may be preceded by intensive training, are only available to sentenced prisoners who are close to release. Prisoner employability is further discussed in Section 4.

In the survey, prisoners were asked what they considered to be their most serious offence. They were to choose from five broad categories. The self-reporting nature of the interviews precluded more accurate classification of these offences in terms of standards such as the Australian Standards Offence Classification and its predecessor, the Australian National Classification of Offences. Nonetheless, under the classification used, over half of the interviewed prisoners reported their most serious offence to be economic in nature (e.g., drug related offences, offences involving money/property). The remainder have committed 'non-economic' offences (e.g., offences against people). The type of offence committed may affect labour market opportunities once prisoners are released. For example, ex-prisoners with offences related to fraud would be unlikely to be successful applicants for positions involving the handling of finances.

It is also important to note that over half of the interviewed prisoners have been incarcerated prior to the current prison period. Moreover, 37\% have been in prison more than once before. This pattern of recidivism is not uncommon across jurisdictions in Australia (Productivity Commission 2004).

Once in prison, each prisoner has a number of choices: work, participate in some education or training course or do nothing. The prisoners' participation in education and training during their current incarceration is summarised in Table 3. In this table, prisoners who were then currently undertaking education or training courses are categorised by the time they have left on their current sentence. ${ }^{6}$ The data show that among prisoners who are participating in educational courses at the time of the survey, $42 \%$ have two years or less remaining on their sentence, $26 \%$ have between three to five years remaining on their sentence and $32 \%$ of prisoners have more than five years remaining on their sentence. Among prisoners who are participating in training at the time of the survey, $40 \%$ have two years or less to serve, $33 \%$ have between three to five years remaining on their sentence and $27 \%$ have more than five years remaining on their sentence. Given the difference in profiles between

\footnotetext{
${ }^{6}$ Time left in prison does not account for possible early release.
} 
those offenders undertaking education and those undertaking training, particularly among those who have more than five years left on their sentence, it would be useful to look at the factors that determine the decision to undertake education or training separately.

Table 3: Education and training at time of the survey by time left of prison sentence

\begin{tabular}{|l|c|c|c|c|c|c|}
\hline Time Left & \multicolumn{3}{|c|}{ Education } & \multicolumn{3}{c|}{ Training } \\
\hline & No & Yes & Total & No & Yes & Total \\
\hline 2 years or less & 158 & 50 & 208 & 163 & 45 & 208 \\
\hline 3 to 5 years & 92 & 31 & 123 & 86 & 37 & 123 \\
\hline More than 5 years & 74 & 38 & 112 & 81 & 51 & 112 \\
\hline Total & 324 & 119 & 443 & 330 & 113 & 443 \\
\hline
\end{tabular}

One of the concerns of prison authorities is the meaningfulness of employment and education/training opportunities within prisons. In the survey, interviewed prisoners were asked three sets of questions. These relate to whether they are currently doing any work, training or education in prison. For those who responded affirmatively to any of these questions, further questions were asked about their job/course. Each of the three sets of questions concludes with a group of questions beginning with "once released from prison, do you think this work experience/training/education will lead to any work?” And ending, for those who answered yes, with a multiple response question on expected type of work - "fulltime work", "part-time work", “casual work", "more money than the job you had before prison" and "a more enjoyable job than you had before prison". 7 These responses were used to create four categories - no work; work; work on higher pay; and more enjoyable work with higher pay.

Table 4 data show the prisoners' job expectations after their release. ${ }^{8}$ Column (i) shows the distribution of prisoners either having no expectation of finding work on release or who are uncertain about their labour market outcome. Column (ii) shows the distribution of prisoners who expect to find work on release. Column (iii) shows the distribution of prisoners who expect to find a better job (work on higher pay or more enjoyable work on higher pay)on release.

\footnotetext{
${ }^{7}$ The prisoners could select more than one category for job expectation.

${ }^{8}$ The sample includes prisoners who engage in any of the prison activities: work, education and training. Some prisoners may be engaging in more than one activity.
} 
Table 4: Future job expectations of prisoners

\begin{tabular}{|l|c|c|c|c|}
\hline Prison activity & $\begin{array}{c}\text { No Work } \\
\text { on Release (i) }\end{array}$ & $\begin{array}{c}\text { Work on } \\
\text { Release (ii) }\end{array}$ & $\begin{array}{c}\text { Better } \\
\text { Job (iii) }\end{array}$ & Total \\
\hline Work & 283 & 63 & 65 & 411 \\
\hline Education & 58 & 35 & 36 & 129 \\
\hline Training & 36 & 41 & 51 & 128 \\
\hline
\end{tabular}

Of the 411 prisoners who worked during their current incarceration, 69\% either believe this will lead to no work on release or are uncertain about their job prospects. It should be noted that working during incarceration may be motivated by the gratuities system. Alternatively, prisoners may be working in mundane jobs which provide no employment prospects outside of prison. ${ }^{9}$ Of those who participate in education, $45 \%$ believe this will lead to no work after release. The distribution of prisoners participating in training and believing there are no job prospects on release is lower at $28 \%$. For both these groups of prisoners, education/training may be used to 'pass the time' or they may simply be uncertain about their employment prospects.

Focusing on those who believe they will have 'good' job prospects, $15 \%$ who worked during incarceration believe this will lead to work after release and $16 \%$ believe this will lead to better jobs. Among the prisoners who participate in education, $27 \%$ expect this will lead to employment after incarceration, a further $28 \%$ believe this will lead to better jobs. Among those who trained during their incarceration, 32\% and $40 \%$ believe this will lead to work and better jobs on release, respectively. These expectations suggest that a non trivial proportion of prisoners who invest in human capital during incarceration do so because they want to improve their labour market outcomes rather than simply 'passing the time'. Moreover, there appears to be a nontrivial difference in the expectation between prisoners who undertake education and those who undertake training during their incarceration.

\section{Methodology}

Models of human capital investment and potential labour market outcomes can be estimated using a logistic framework. In this framework the propensity towards a particular activity (j) for prisoner (i) can be expressed as:

$$
P_{j i}^{*}=\beta_{j} X_{j i}+\varepsilon_{j i}
$$

\footnotetext{
${ }^{9}$ As mentioned before, prisoners can work in commercial industries or domestic work. About $29 \%$ of the prison sample is employed in commercial industries.
} 
$P_{j i}^{*}$ is a latent variable that captures the propensity towards a particular activity, $X$ is a column vector of observed factors, $\beta$ is a row vector of coefficients and $\varepsilon$ is a random error term. ${ }^{10}$ We do not observe the propensity towards a particular activity (e.g., participation in education/training, finding a job) but rather the actual outcome of the decision-making process. This outcome can be described by a binary indicator that corresponds to particular values of $P^{*}$ in the model. For example, the observed binary outcome variable might be 1 where $P^{*} \geq 0$ and zero otherwise.

With the logit model, the natural logarithm of the odds ratio is, for example, the ratio of the probability of participation $(P)$ to the probability of non-participation $(1-P)$, and $\log \left[\frac{P}{1-p}\right]$ is expressed as a linear combination of the explanatory variables, namely $\log \left[\frac{P}{1-P}\right]=\beta_{j} X_{j i}$. The parameter estimates in the logit model therefore record the impact on the logarithm of the odds ratio of a small change in the explanatory variables. The following discussion refers to three different formalisations of this generic model.

First, to model the prisoners' educational attainment prior to current incarceration, the dependent variable equals unity if the prisoners completed Year 12 or higher and is zero if they complete Year 11 or lower. Some of the explanatory variables are based on the standard models of educational attainment from previous research (e.g., Vella 1994; Le and Miller 2004a) and contain personal characteristics (age, gender, ATSI, overseas born), type of school attended and parents’ occupational attainment.

We can make inferences about whether the prisoners invest in human capital by participating in education/training during incarceration or their participation is for consumption. We hypothesise that prisoners who want to invest in human capital will participate in education/training closer to their release date in preparation for re-entry into the labour market. Prisoners who see education/training as consumption are more likely to participate in these activities earlier in their sentence as they are not interested in possessing the latest skills in preparation for re-entry into the labour market. Hence, the decision to participate in education/training is analysed separately for prisoners at various stages of their prison term. The dependent variable is equal to

\footnotetext{
${ }^{10}$ See Appendix A for definitions of variables.
} 
unity if the prisoner participates in education or training at the time of the survey and is equal to zero if they do not. ${ }^{11}$ The explanatory variables include personal characteristics, prison information (e.g., type of prison, type of offence). Separate analyses are undertaken for prisoners who have two years or less remaining on their sentence, three to five years remaining on their sentence and more than five years remaining on their sentence. This allows us to identify if there are differences in the decision to invest in education/training among prisoners who are at various stages of their prison sentence.

To take into account that educational/training courses can be offered at different times and the availability of courses can vary over the prisoners' sentence, time already served during the current sentence is included in the model. In addition, time already served during the current sentence can have different effects across prison length. For prisoners who are coming to the end of their sentence (two years or less), if they view education/training as an investment in human capital rather than as consumption they are more likely to defer their participation in these activities closer to their release date in preparation for re-entry into the labour market. Hence, time already served in prison is expected to have a positive effect on current participation in education/training. For prisoners who have a large proportion of their sentence still to serve (three or more years) we can expect time already served to have a negative impact on current participation in education/training. That is, these prisoners are deferring their education/training closer to their release in preparation for re-entry into the labour market.

A third set of models is used to assess the potential benefits of investing in education/training during incarceration. Two models are estimated. The first of these is for the prisoner's expectation of finding a job on release, the second is for the prisoners' expectation of finding a better job on release. The explanatory variables include personal characteristics, type of offence committed, length of sentence and whether the prisoners have completed any educational or training courses during the current prison term. The models are estimated for all prisoners. It should be noted that prisoners are able to engage in work at the same time.

\footnotetext{
${ }^{11}$ Prisoners who participate in both education and training are not included in the analysis. This represents $5 \%$ of the sample.
} 


\section{RESULTS}

Educational attainment prior to current incarceration

Table 5: Logistic regression results for educational attainment prior to current incarceration

\begin{tabular}{|l|c|}
\hline Variable & Coefficient \\
\hline Constant & -1.479 \\
& $(-1.29)$ \\
\hline Male & -0.195 \\
& $(-0.72)$ \\
\hline Age & 0.028 \\
& $(0.54)$ \\
\hline Age $^{2}$ & -0.026 \\
& $(-0.41)$ \\
\hline ATSI & -0.692 \\
& $(-2.12)^{*}$ \\
\hline Overseas born & 0.561 \\
& $(2.13)^{*}$ \\
\hline Attend government school & -0.950 \\
& $(-3.72)^{*}$ \\
\hline Siblings & 0.701 \\
& $(1.13)$ \\
\hline Parents' highest occupation & 0.677 \\
& $(2.90)^{*}$ \\
\hline \multirow{2}{*}{$\chi^{2}(8)$} & 40.573 \\
\hline Pseudo-R ${ }^{2}$ & 0.0730 \\
\hline Mean of dependent variable & $30.96 \%$ \\
\hline Sample & 449 \\
\hline
\end{tabular}

Note: t-ratios are in parentheses. * denotes statistical significance at the $10 \%$ level or higher.

Table 5 presents the logistic regression results for the educational attainment of prisoners prior to their current incarceration. Summarily, 31\% of prisoners have completed Year 12 or higher. Overall, the results conform to a priori expectations. The standard variables which significantly affect educational attainment of prisoners include, birthplace, attending a government school and parents' occupational status. Compared to prisoners who attended Catholic or other independent schools, those who attended government schools are less likely to complete Year 12 or higher. The difference in schooling outcome between government and non-government school could reflect teachers, school facilities and/or cohort of students (e.g., Le and Miller 2004b). Parents' occupational status is used to capture not only socioeconomic circumstance but also the level of guidance parents are able to provide to their children schooling. Table 5 shows that prisoners with one or both parents employed in managerial, professional or paraprofessional occupations are more likely to complete 
Year 12 or higher compared to prisoners whose parents are employed in other occupations such as labourer. Overall, the results obtained from the current data set are comparable to those obtained in the literature.

\section{Investment in human capital during incarceration}

Table 6 shows the propensity of prisoners' participation in education and/or training at the time of the survey. ${ }^{12}$ The column (i) results pertain to prisoners who have two years or less remaining on their prison sentence. The column (ii) results are for prisoners who have between three and five years remaining on their sentence. Finally, the column (iii) results cover prisoners who have more than five years remaining on their sentence. This approach allows us to look at human capital investment at different stages of the prison sentence. ${ }^{13}$

Overall, there are noticeable differences in the determinants of the decision to participate in education/training across the time remaining on the prison term. Focusing first on the column (i) results, it can be seen that for prisoners who are near the end of their prison sentence (two years or less), the level of optimism and their intention to start a new job are important reasons why they choose to participate in education/training. Hence, the more optimistic the prisoners are the more likely they will participate in education/training just prior to their release. Furthermore, prisoners who expect to move to a new job, or look for a better job, are more likely than those who expect not to re-enter into the labour market or have no definite plans after their release, to participate in education/training just prior to their release. This suggests that education/training is used by these prisoners as an investment, that is, to improve their skills in preparation for their impending release. ${ }^{14}$

\footnotetext{
${ }^{12}$ The sample includes prisoners who participate in both education and training courses as well as those who participate in either of these activities only. In addition, prisoners who are currently working and participating in education and/or training are also included in the analysis.

${ }^{13}$ A pooled model of all prisoners was also estimated with dummy variables for length of sentence remaining. The results are similar to those obtained in Table 6.

${ }^{14}$ Entorf (2009) found that prisoners with poor labour market prospects (e.g., do not have a job which they can return to after imprisonment) expect a significantly higher rate of future recidivism.
} 
Table 6: Logistic regression results for participation in education and/or training at the time of the survey

\begin{tabular}{|l|c|c|c|}
\hline Variable & S 2 years (i) & 3 - 5 years(ii) & > 5 years (iii) \\
\hline Constant & Coefficient & Coefficient & Coefficient \\
\hline Male & -0.708 & 0.952 & 2.049 \\
& $(-1.02)$ & $(0.80)$ & $(1.53)$ \\
\hline Optimism index & -0.507 & -2.225 & -1.018 \\
& $(-1.25)$ & $(-2.30)^{*}$ & $(-1.13)$ \\
\hline Return to old job & 0.060 & 0.036 & -0.033 \\
& $(1.92)^{*}$ & $(0.75)$ & $(-0.66)$ \\
\hline New job & 0.110 & -0.026 & -0.867 \\
& $(0.32)$ & $(-0.06)$ & $(-1.53)$ \\
\hline Minimum-security prison & 1.263 & -0.183 & 0.340 \\
& $(2.09)^{*}$ & $(-0.33)$ & $(0.54)$ \\
\hline Drugs/economic-related crimes & 0.029 & 0.270 & 0.203 \\
& $(0.07)$ & $0.35)$ & $(0.28)$ \\
\hline Been in prison & -0.317 & 0.178 & -0.934 \\
& $(-0.99)$ & $0.43)$ & $(-1.88)^{*}$ \\
\hline Months spent in prison & -0.450 & 0.020 & -0.425 \\
& $(-1.44)$ & $(0.05)$ & $(-0.87)$ \\
\hline Completed education & -0.0008 & -0.015 & -0.009 \\
& $(-0.45)$ & $(-1.86)^{*}$ & $(-0.10)$ \\
\hline Completed training & -0.074 & 0.494 & 1.130 \\
& $(-0.19)$ & $(1.12)$ & $(2.31)^{*}$ \\
\hline \multirow{2}{*}{$\chi^{2}(10)$} & -0.376 & 0.589 & 2.243 \\
\hline Pseudo-R ${ }^{2}$ & $(-0.55)$ & $(0.68)$ & $(1.84)^{*}$ \\
\hline Mean of dependent variable & & & \\
\hline Sample & 14.949 & 16.017 & 29.831 \\
\hline Nent- & 5.264 & 9.553 & 19.524 \\
\hline & 208 & $48.760 \%$ & $54.955 \%$ \\
\hline & 121 & 111 \\
\hline
\end{tabular}

Note: t-ratios are in parentheses. * denotes statistical significance at the $10 \%$ level or higher.

Among prisoners who have between three and five years remaining on their sentence (column ii), gender and the time already spent in prison are important factors determining their propensity to participate in education/training at the time of the survey. For example, male prisoners are less likely than female prisoners to participate in education/training if they have three to five years remaining of their sentence to serve.

The coefficients reported in column (ii) show that prisoners who still have between three and five years remaining on their prison sentence are less likely to currently participate in education/training the longer the time they have already spent in prison. However, the inference that prisoners use education/training as investment in human capital rather than consumption is relatively weak given the "months spent in prison” variable is not significant for prisoners who either have two years or less 
remaining on their sentence or those who have more than five years remaining on their sentence. It is possible that where the prisoners are in their prison term could impose a time constraint that dictates whether they can participate in education/training.

Among prisoners who have more than five years remaining on their sentence, the types of offence committed and completion of education/training during the current prison term are important determinants of participation in education/training at the time of the survey. Compared to prisoners who have committed serious offences (e.g., offences involving people), those who committed drug-related or economic offences are less likely to participate in education/training. The results also show that prisoners who have completed an educational qualification and training during the current prison term are more likely to undertake further education/training.

It is possible that there is some degree of selection bias in the sample of prisoners who responded to this survey. That is, prisoners who have participated in prison activities are more willing to participate in the survey, particularly as the letter of invitation to participate in the project stated that the survey was looking at what education or training they did before coming to prison, what jobs they had before coming to prison, what education or training they were doing in prison, what work they were doing in prison, and what they thought about future job prospects.

In addition, the low response rate from a male-maximum security prison could also reflect sample selection bias. To remove the bias associated with this latter factor, the analyses are repeated without prisoners from the male maximum-security prison. The results are quite robust across samples. The only outcome affected by this omission is for prisoners who were close to their release date (two years or less). For these prisoners, the level of optimism is no longer significant. Moreover, there is a significant difference between repeat and non-repeat offenders. For prisoners who have three or more years remaining on their sentence, the results do not change. ${ }^{15}$ Hence, we can be reasonably confident that the results are not driven by biases which may arise due to sample selection.

To examine if prisoners who participate in education or training differ in their characteristics, separate models are estimated for participation in education and training. The results are presented in Tables 7 and 8 . Note that prisoners who were

\footnotetext{
${ }^{15}$ Results can be obtained from the authors.
} 
then enrolled in both general education and vocational-specific training courses are omitted from the analysis.

The mean statistics reveal that there is a non-trivial difference in the proportion of prisoners who currently participate in education who are towards the end of their prison term and those who still have five years or more remaining on their sentence. Moreover, the results in Table 7 show that there are differences in the decision to participate in education between prisoners at various stages of their prison term. Among prisoners who are near the end of their prison term (column i) a high level of optimism is associated with a high propensity to participate in education.

Table 7: Logistic regression results for participation in education at the time of the survey

\begin{tabular}{|l|c|c|c|}
\hline Variable & 5 2 years (i) & 3 - 5 years(ii) & > 5 years (iii) \\
\hline & Coefficient & Coefficient & Coefficient \\
\hline Constant & -1.940 & -0.167 & 1.710 \\
& $(-2.21)^{*}$ & $(-0.12)$ & $(1.25)$ \\
\hline Male & -0.322 & -2.712 & -1.825 \\
& $(-0.68)$ & $(-2.16)^{*}$ & $(-1.71)^{*}$ \\
\hline Optimism index & 0.087 & -0.008 & -0.056 \\
& $(2.21)^{*}$ & $(-0.13)$ & $(-1.05)$ \\
\hline Return to old job & -0.034 & 0.590 & -1.208 \\
& $(-0.08)$ & $(0.95)$ & $(-1.71)^{*}$ \\
\hline New job & 0.029 & 0.495 & -29.326 \\
& $(0.04)$ & $(0.67)$ & $(-0.000)$ \\
\hline Minimum-security prison & -0.417 & 0.823 & 1.630 \\
& $(-0.92)$ & $(0.69)$ & $(1.72)^{*}$ \\
\hline Drugs/economic-related crimes & -0.559 & 0.137 & -1.351 \\
& $(-1.48)$ & $(0.25)$ & $(-2.25)^{*}$ \\
\hline Been in prison & -0.328 & 0.170 & -0.731 \\
& $(-0.87)$ & $(0.33)$ & $(-1.21)$ \\
\hline Months spent in prison & -0.00008 & -0.002 & -0.003 \\
& $(-0.04)$ & $(-0.21)$ & $(-0.24)$ \\
\hline Completed training course & -0.413 & 1.509 & 3.220 \\
& $(-0.50)$ & $(1.72)^{*}$ & $(2.44)^{*}$ \\
\hline \multirow{2}{*}{$\chi^{2}(9)$} & & & \\
\hline Pseudo-R ${ }^{2}$ & 11.829 & 12.585 & 31.527 \\
\hline Mean of dependent variable & 5.559 & 11.065 & 25.369 \\
\hline Sample & $21.782 \%$ & $20.536 \%$ & $29.126 \%$ \\
\hline
\end{tabular}

Note: t-ratios are in parentheses. * denotes statistical significance at the $10 \%$ level or higher.

Among prisoners who have between three and five years remaining on their prison sentence to serve, male prisoners are less likely than female prisoners to participate in education. In addition, prisoners who have already completed a traineeship during this prison term are more likely to subsequently participate in 
education than those who have not completed a traineeship. This suggests that training courses may not be substitutes for educational courses.

There are considerable differences between the determinants of the decision of prisoners to participate in education for those who are near the end of their sentence and those who still have more than five years remaining. For example, male prisoners who have more than five years remaining on their sentence are less likely than female prisoners to participate in education. It is interesting to note that prisoners who intend to go back to the job held prior to current imprisonment are less likely to participate in education. This further suggests education is not used for consumption. Similarly, prisoners who committed drug- or economic-related offences are less likely than those who committed other offences to participate in education. Prisoners held in minimumsecurity prisons are more likely to participate in current education than those who are in maximum-security prisons. This is not unexpected as education courses off site (for example, undergraduate study at university or senior school subjects offered by a local TAFE) are not available to maximum-security prisoners, thus limiting their study choices. Having completed a training course during this prison term enhances participation in education among prisoners who have more than five years of their sentence still to serve. ${ }^{16}$

Table 8 contains the results for current participation in training for prisoners at various stages of their sentence. While the models have less explanatory power than in the case of participation in education, they are statistically significant overall. The only variable which significantly affects the prisoners' propensity to participate in training is their intention to start a new job or look for a better job. These prisoners are more likely to participate in training than those who had no plans to re-enter the labour market or had no definite plans after their release. This result reinforces the notion that prisoners who have a clear intention of re-entering the labour market after imprisonment use education/training to improve their labour market potential.

\footnotetext{
${ }^{16}$ Inclusion of the variable for completion of education courses does not alter the results for prisoners who are near the end of their prison term. However, it does affect the decision to participate in education among prisoners who have more than five years remaining on their sentence. The variables for gender, returning to old job and minimum-security prison become insignificant. There is a significant difference in the propensity to participate in training between prisoners who have completed an educational qualification during this prison term and those who have not.
} 
Table 8: Logistic regression results for participation in training at the time of the survey

\begin{tabular}{|l|c|c|c|}
\hline Variable & S 2 years (i) & 3 - 5 years(ii) & > 5 years (iii) \\
\hline & Coefficient & Coefficient & Coefficient \\
\hline Constant & -1.688 & -1.856 & -1.192 \\
& $(-1.85)^{*}$ & $(-1.23)$ & $(-0.81)$ \\
\hline Male & -0.338 & 0.361 & -0.094 \\
& $(-0.64)$ & $(0.35)$ & $(-0.10)$ \\
\hline Optimism index & 0.011 & 0.056 & 0.025 \\
& $(0.28)$ & $(0.95)$ & $(0.44)$ \\
\hline Return to old job & 0.237 & -0.249 & -0.017 \\
& $(0.54)$ & $(-0.47)$ & $(-0.02)$ \\
\hline New job & 1.519 & -0.606 & 2.094 \\
& $(2.50)^{*}$ & $(-0.92)$ & $(2.80)^{*}$ \\
\hline Minimum-security prison & 0.408 & -0.210 & -0.241 \\
& $(0.78)$ & $(-0.25)$ & $(-0.30)$ \\
\hline Drugs/economic-related crimes & 0.010 & 0.108 & -0.412 \\
& $(0.02)$ & $(0.23)$ & $(-0.71)$ \\
\hline Been in prison & -0.046 & -0.032 & -0.051 \\
& $(-0.12)$ & $(-0.07)$ & $(-0.09)$ \\
\hline Months spent in prison & -0.008 & -0.023 & -0.010 \\
& $(-0.71)$ & $(-1.31)$ & $(-0.91)$ \\
\hline Completed education course & -0.774 & 0.033 & -0.284 \\
& $(-1.31)$ & $(0.07)$ & $(-0.50)$ \\
\hline \multirow{2}{*}{$\chi^{2}(9)$} & & & \\
\hline Pseudo-R ${ }^{2}$ & 12.808 & 4.700 & 9.619 \\
\hline Mean of dependent variable & 6.462 & 3.745 & 10.522 \\
\hline Sample & $19.309 \%$ & $24.779 \%$ & $22.330 \%$ \\
\hline
\end{tabular}

Note: t-ratios are in parentheses. * denotes statistical significance at the $10 \%$ level or higher.

A comparison between the results for current participation in education and training suggests that prisoners consider these are separate and distinct activities with different appeal. Moreover, the set of variables that are associated with prisoners' propensity to participate in education are generally not the same as those associated with their propensity to participate in training.

\section{$\underline{\text { Potential labour market outcomes }}$}

Potential labour market outcome refers to the prisoners' perception of their labour market future only. Thus the probabilities discussed here are therefore probabilities based on prisoner expectations. For example, in Table 9 the results for the expected probabilities of finding a job (column i) and finding a better job (column ii) are presented. Overall, the factors that affect the propensity of prisoners to expect to find a job after imprisonment are the same as those that affect their propensity to 
expect to find a better job. For example, the expected probabilities of finding a job and finding a better job decline among older prisoners. This is consistent with a decline in employability among older age groups (e.g., Le and Miller 2000). Male prisoners are less likely to expect to find a job or find a better job after their release than female prisoners ${ }^{17}$.

With regard to prison-related variables, type of offence and completion of education/training courses during the current prison term are significant determinants of the expected propensity to find a job or find a better job. Compared to prisoners who have committed offences against people, those who have committed drug- or economic-related offences are less likely to expect to find a job or find a better job after incarceration.

To further explore the nature of the offences committed and how these impact on the expected employment prospects of prisoners after incarceration, the types of offence were categorised into three groups: drugs-related, (other) economic-related offences and offences committed against people. The results show that with respect to finding a job, those who have committed drugs-related offences are less likely to expect to find a job than those who have committed offences against people. There is no significant difference in the expectation of employment between prisoners who committed economic-related offences and those who committed offences against people. With regard to finding a better job, those who committed economic-related offences are less likely to expect to find a better job after incarceration than those who committed offences against people. However, there is no significant difference in the expected propensity to find a better job between prisoners who committed drugsrelated offences and those who committed offences against people.

The Table 9 results also show that, compared to prisoners who have not completed an education or training course during their (then) current prison sentence, those who have are more likely to expect to find a job or find a better job after incarceration. This suggests prisoners do value investment in human capital and expect some positive outcome from their investment. While the probability of finding a job or a better job is higher for prisoners who have completed a training course compared to those who have completed an educational course, the difference is not

${ }^{17}$ Cho and LaLonde (2005) found that incarceration does not appear to harm the employment prospects of women. 
statistically significant. Hence, there is no significant difference in the expected benefit between participation in education and training.

Table 9: Logistic regression results for labour market expectations

\begin{tabular}{|l|c|c|}
\hline Variable & Finding a job (i) & Finding a better job (ii) \\
\hline Constant & Coefficient & Coefficient \\
\hline Male & 1.147 & 0.030 \\
& $(1.98)^{*}$ & $(0.05)$ \\
\hline Age & -0.541 & -0.668 \\
& $(-2.11)^{*}$ & $(-2.48)^{*}$ \\
\hline ATSI & -0.036 & -0.031 \\
& $(-3.40)^{*}$ & $(-2.56)^{*}$ \\
\hline Professional occupation & 0.084 & 0.117 \\
& $(0.31)$ & $(0.40)$ \\
\hline Optimism index & 0.019 & 0.013 \\
& $(0.85)$ & $(0.53)$ \\
\hline Drugs/economic-related crimes & -0.230 & -0.080 \\
& $(-0.84)$ & $(-0.19)$ \\
\hline Been in prison & -0.536 & -0.467 \\
& $(-2.51)^{*}$ & $(-1.96)^{*}$ \\
\hline Prison length & -0.035 & 0.163 \\
& $(-0.17)$ & $(0.67)$ \\
\hline Completed education course & 0.003 & 0.277 \\
& $(1.39)$ & $(1.34)$ \\
\hline Completed training course & 0.487 & 0.490 \\
& $(2.13)^{*}$ & $(1.97)^{*}$ \\
\hline & 0.792 & 0.943 \\
$\chi^{2}$ (10) & $(1.72)^{*}$ & $(2.16)^{*}$ \\
\hline Pseudo-R ${ }^{2}$ & & 31.347 \\
\hline Mean of dependent variable & 38.132 & 6.158 \\
\hline Sample & 6.278 & $26.652 \%$ \\
\hline Note & $47.380 \%$ & 439 \\
\hline
\end{tabular}

Note: t-ratios are in parentheses. * denotes statistical significance at the $10 \%$ level or higher. 


\section{CONCLUSION}

Long gone are the days when we lock up prisoners and throw away the key. Today, policy makers recognise the potential economic and social costs of recidivism and incarceration. Hence, the management of prisoners has changed. Prisoners are now encouraged to actively participate in education/training and/or work during their incarceration. This paper attempts to explain education/training choices by prisoners during their incarceration. We attempt to distinguish between the human capital investment and consumption components of participation in education and training. To assess the potential labour market outcomes of human capital investment and implicit value prisoners place on education/training, the expectation of finding a job and finding a better job after incarceration are also examined.

The results suggest prisoners who are more precise about their re-entry into the labour market after imprisonment are more likely to use education and training to improve their skills. However, the decision to participate in either education or training appears to be quite different, suggesting that these are distinct activities. Furthermore, there are significant differences in the prisoners' participation in education and training between those who are close to the end of their prison term and those who still have a long time remaining on their sentence. While we can infer from the results that prisoners are using education and training as investment in human capital rather than consumption, this inference is tentative and further research is required.

With regard to the value prisoners place on education and training, the results suggest those who had already completed educational or training courses during their incarceration have a higher expectation of finding a job or a better job after release. However, the expected benefit prisoners place on education and training appears to be the similar. This presents us with a quandary, if the decision to participate in education or training is separate and non-random, then why are prisoners' expectations of labour market outcomes from these activities similar? Further research into the prisoners' actual labour market outcomes after incarceration may help clarify some of the discrepancy.

This paper provides an overview into the propensity for prisoners to participate in prison activities such as education and training and how prisoners expect to interact with the labour market on their release. However, there are two developments that may challenge these. First, in an environment with slowing 
economic growth, workers who are most vulnerable to lay-offs are low-skilled such as many ex-prisoners. Hence it is important that prison authorities understand the choices prisoners make during incarceration if they wish to enhance the delivery and participation of education and training during incarceration. In this regard information on whether the prisoners view education/training as investment in human capital or consumption will be useful.

A second issue of concern is changes within the VET system. For example, Anderson (2006) in his evaluation of the impact and outcomes of market reform in VET nationally, states that, if the predisposition for efficiency rather than equity improvements continues, then "there is a risk that publicly funded VET markets will become inaccessible and inequitable for ....disadvantaged groups with adverse ramifications for labour market participation and social inclusion” (p.30). Exprisoners are one such disadvantaged group. It would be disappointing to see the inroads made into improving access to and participation in VET within offender management programs (see Wynes 2007 for more specific details of VET for adult prisoners across Australia) eroded by outsourcing and other cost saving measures. 


\section{REFERENCES}

Anderson, D. (2006). Trading Places: The Impact and Outcomes of Market Reform in Vocational Education and Training, NCVER, Australian National Training Authority.

Australian Bureau of Statistics (2001). "Successful and Unsuccessful Job Search Experience”, Catalogue No. 6245.0, ABS, Canberra.

Australian Bureau of Statistics (2008). "Prisoners in Australia 2008”, Catalogue No. 4517.0, ABS, Canberra.

Australian National Training Authority (2001). National Strategy for Vocational Education and Training for Adult Prisoners and Offenders in Australia, ANTA, Brisbane.

Batchelder, J. and Pippert, J. (2002). "Hard Time Or Idle Time: Factors Affecting Inmate Choices between Participation in Prison Work and Education Programs”. The Prison Journal, Vol. 82 (2), pp.269-280.

Bearing Point (2003). "Education and Training Provision in Victoria Prisons: The Way Forward”, Discussion Paper, Office of Correctional Services Commissioner, Melbourne.

Boshier, R. and Johnson, D. (1974). "Does Conviction Affect Employment Opportunities?” British Journal of Criminology, Vol. 14 (3), pp.264-280.

Chavez, R. and Dawe, S. (2007). 'International Research and Trends in Education and Training Provision in Correctional Settings”, in Dawes, S. (Ed.). Vocational Education and Training for Adult Prisoners and Offenders in Australia: Research Readings, National Centre for Vocational Education Research, Adelaide.

Cho, R. and LaLonde, R. (2005). "The Impact of Incarceration in State Prison on the Employment Prospects of Women”, IZA Discussion Paper No. 1792.

Commonwealth of Australia (2008). Australian Government 2007-08 Commonwealth Budget, Commonwealth of Australia, Canberra, ACT.

Cook, K. (1990). “The Offender's Point of View”, Paper presented at the Keeping People Out of Prison Conference, 27-29 March, Australian Institute of Criminology, Canberra.

Dawe, S. (2007). "Introduction”, in Dawes, S. (Ed.). Vocational Education and Training for Adult Prisoners and Offenders in Australia: Research Readings, National Centre for Vocational Education Research, Adelaide.

Fakhourya, W. and Priebea, S. (2007). "Deinstitutionalization and Reinstitutionalization: Major Changes in the Provision of Mental Healthcare", Psychiatry, Vol. 6 (8), pp.313-316. 
Giles, M., A.T. Le, M. Allan, C. Lees, A-C. Larsen and L. Bennett. (2004). “To Train or Not to Train: The Role of Education and Training in Prison to Work Transitions”, NCVER, Australian National Training Authority.

Graffam, J., Shinkfield, A., Lavelle, B. and Hardcastle, L. (2004). "Attitudes of Employers, Corrective Services Workers, Employment Support Worker, and Prisoners and Offenders towards Employing Ex-prisoners and Ex-offenders”, Report to the Criminology Research Council, School of Health and Social Development, Deakin University.

Haigler, K., Harlow, C., O’Connor, P. and Campbell, A. (1994). “Literacy Behind Prison Walls”, http://www.nces.ed.gov/pubs94/94102.pdf

Hamyn, B. and Lewis, D. (2000). "Home Office Research Study of 208 Women Prisoners: A Survey of Their Work and Training Experiences in Custody and on Release”, http://www.homeoffice.gov.uk/rds/pdfs/hors208.pdf

Harrison, P.M. and Beck, A.J. (2005). "Prisoners in 2004”, Bureau of Justice Statistics Bulletin, October.

Helfgott, J. (1997). "Ex-offender Needs Versus Community Opportunity in Seattle, Washington”, Federal Probation, Vol. 61 (2), pp.12-25.

Holzer, H., Raphel, S. and Stoll, M. (2002). "Will Employers Hire Ex-offenders? Employer Preferences, Background Checks, and Their Determinants", Discussion Paper No. 1243-02, Institute for Research on Poverty, http://www.irp.wisc.edu/

Kling, J.R. (2006). “Incarceration Length, Employment, and Earnings”, American Economic Review, Vol. 96 (3), pp.863-876.

Kling, J. and Krueger, A. (2001). “Costs, Benefits and Distributional Consequences of Inmate Labor”, Working Paper No. 449, Princeton University Industrial Relations Section, Princeton, NJ.

Le, A.T. and Miller, P.W. (2000). "An Evaluation of Inertia Models of Unemployment”, Australian Economic Review, Vol. 33 (3), pp.205-220.

Le, A.T. and Miller, P.W. (2004a). "School Leaving Decisions in Australia: A Cohort Analysis”, Education Economics, Vol. 12 (1), pp.39-66.

Le, A.T. and Miller, P.W. (2004b). "High School Graduation in Australia: Do Schools Matter?”, Scottish Journal of Political Economy, Vol. 51 (2), pp.194-208.

Lochner. L. and Moretti, E. (2004). "The Effect of Education on Crime: Evidence From Prison Inmates, Arrests, and Self-Reports”, American Economic Review, Vol. 94 (1), pp.155-189. 
Moore, J. (1996). "Bearing the Burden: How Incarceration Weakens Inner-City Communities", in The Unintended Consequences of Incarceration, Vera Institute of Justice, New York.

New Zealand Department of Corrections (2003). "Census of Prison Inmates and Home Detainees 2001", http://www.corrections.govt.nz/pdf/research/census/census2001.pdf

Petersilia, J. (2000). "When Prisoners Return to the Community: Political, Economic, and Social Consequences”, Sentencing and Corrections: Issues for the $21^{\text {st }}$ Century, Issue 9, pp.1-7.

Productivity Commission (2004). "Report on Government Services 2004", Productivity Commission, Canberra.

Reuss, A. (1999). “Prison(er) Education”, The Howard Journal, Vol. 38 (2), pp.113127.

Riddell, W.C. (2006). “The Impact of Education on Economic and Social Outcomes: an Overview of Recent Advances in Economics”, Canadian Policy Research Network Inc, http://www.cprn.com.document/44362 en.pdf

Scheier, M.F. and Carver, C.S. (1987). "Dispositional Optimism and Physical wellBeing: The Influence of Generalized Outcome Expectancies on Health”, Journal of Personality. Vol. 55 (2), pp.169-210.

Senate Employment, Education and Training References Committee (1996). Report of the Inquiry into Education and Training in Correctional Facilities, Australian Government Publishing Service, Canberra.

Singley, S. (2004). "Barriers to Employment Among Long-term Beneficiaries: A Review of Recent International Evidence”, Working Paper 04/04, Centre for Social Research and Evaluation, Ministry of Social Development, New Zealand.

Social Exclusion Unit Great Britain (2002). "Reducing Re-offending by exPrisoners”, http://www.socialexclusionunit.gov.uk/publications/reports/html/Reducing_reoffending.

Steurer, S., Smith, L. and Tracey, A. (2001). "Education Reduces Crime: Three-State Recidivism Study”, http://www.ceanational.org

The United Nations Asia and Far East Institute for the Prevention of Crime and the Treatment of Offenders (UNAFEI) (2008). "Promoting Public Safety and Controlling Recidivism Using Effective Interventions with Offenders Whilst Serving Their Sentences: An Examination of Best Practices”, Resource Materials Series No. 74. http://www.uafei.or.jp/english/pages/PublicationsRMS.htm 
Vella, F. (1994). “Gender Roles and Human Capital Investment: The Relationship between Traditional Attitudes and Female Labour Market Performance”, Economica, Vol. 61 (242), pp.191-211.

Western Australian Department of Corrective Services (2006). Profile of Women in Prison 2005, Government of Western Australia, Perth.

Western Australian Department of Justice (2008), Department of Justice Annual Report 2007/08, Government of Western Australia, Perth.

Western Australian Department of Corrective Services (2009). Adult Offenders in Custody.

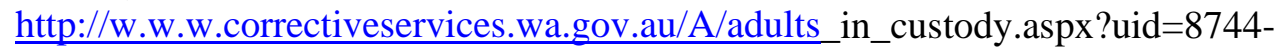
4513-1513-5758.

Wynes, S,H. (2007). "The Provision of VET for Adult Prisoners in Australia” in Dawes, S. (Ed.). Vocational Education and Training for Adult Prisoners and Offenders in Australia: Research Findings, National Centre for Vocational Education Research, Adeliade. 


\section{APPENDIX A DEFINITION OF VARIABLES}

Dependent variables

Completed Year 12 or higher: This variable is set equal to unity if the prisoner completed Year 12 or higher prior to their current incarceration. The benchmark group is prisoners who completed Year 11 or lower.

Education/training: This variable is set equal to unity if the prisoner participates in education/training during their incarceration. If the prisoner participates in education/training and work they are grouped as participate in education/training. The benchmark group is prisoners who work only and those who do not participate in any prison activities during their current incarceration.

Current participation in education: This variable is set equal to unity if the prisoner currently participates in an educational course (s).

Current participation in training: This variable is set equal to unity if the prisoner is currently participating in a training course (s).

Finding a job: This variable is set equal to unity if the prisoner expects to find a job after incarceration. The benchmark group is prisoners who do not expect to find work or who are uncertain about their labour market outcome after leaving prison.

Finding a better job: This variable is set equal to unity if the prisoner expects either to find a higher paid job or a more interesting job after incarceration. The benchmark group is prisoners who do not expect to find a higher paid job or a more interesting job after incarceration.

Explanatory Variables

Male: This variable is set equal to unity if the prisoner is male. The benchmark group is female prisoners.

Age: The prisoner's age in years.

ATSI: This variable is set equal to unity if the prisoner is Aboriginal or Torres Strait Islander. The benchmark group is prisoners of other origin.

Overseas born: This variable is set equal to unity if the prisoner was born outside of Australia. The benchmark group is prisoners who were born in Australia.

Attended government school: This variable is set equal to unity if the prisoner attended a government/public school. The benchmark group is prisoners who attended Catholic or other Independent schools.

Siblings: This variable is set equal to unity if the prisoner has one or more siblings. The benchmark group is prisoners who do not have siblings. 
Parents' highest occupation: This variable is set to unity if either parent has a managerial, professional or paraprofessional occupation. The benchmark group is prisoners whose parents are employed in other occupations (e.g., labourer).

Optimism index: This variable has a valid range from 0 to 32 points. High values indicate a high degree of optimism whereas low values indicate a low degree of optimism. The index is computed from responses to eight statements from the Life Orientation Test (LOT) of Scheier and Carver (1987). The optimism index (LOT score) is the sum of the response values (details can be obtained from the author).

Been in prison: This variable is set equal to unity if the prisoner has been imprisoned prior to their current incarceration. The benchmark group is prisoners who had not been to prison before.

Prison length: This is a continuous variable and measures the length of the current prison term in months.

Minimum-security prison: This variable is set equal to unity if the prisoner is currently in a minimum-security prison. The benchmark group is prisoners who are in a maximum-security prison, including prisoners with maximum and other security levels.

Drugs/economic - related crimes: This variable is set equal to unity if the prisoner has committed an offence involving drugs, money and property or other offences not related to people. The benchmark group is prisoners who committed offences involving money and property against people or offences against people.

Work in prison industry: This variable is set equal to unity if the prisoner works in a prison industry (commercial work). The benchmark group is prisoners who do domestic or no work.

Professional occupation: This variable is set equal to unity if the prisoner was employed in managerial, professional or paraprofessional occupations in the five years prior to their current imprisonment. The benchmark group is prisoners who were employed in other occupations (e.g., labourer).

\section{Labour market intentions}

Return to old job: This variable is set equal to unity if the prisoner intends to return to the last paid job.

New job: This variable is set equal to unity if the prisoner intends to start a new career, work in another company, open their own business, been offered a new job or look for a better job after incarceration.

The benchmark group is prisoners who do not intend to re-enter the labour market after incarceration or who are uncertain about their labour market participation. 